\title{
DAMPAK LIMBAH CAIR RUMAH POTONG HEWAN SAPI TERHADAP KUALITAS AIR DRAINASE DI NIPAH KUNING KOTA PONTIANAK
}

\author{
Supriyatin ${ }^{1)}$ Johnny MTS ${ }^{2)}$ Endang Mulyani ${ }^{2)}$ \\ ${ }^{1)}$ Program Studi Teknik Lingkungan Jurusan Teknik Sipil Fakultas Teknik Universitas Tanjungpura, Pontianak \\ 2) Program Studi Teknik Sipil Jurusan Teknik Sipil Fakultas Teknik Universitas Tanjungpura, Pontianak \\ Email : atinaatin27@gmail.com
}

\begin{abstract}
ABSTRAK
Seiring bertambahnya kebutuhan daging pada masyarakat maka keberadaan Rumah Potong Hewan (RPH) Sapi yang baik (bersih, sehat, dan halal dikonsumsi) sangat diperlukan. RPH sapi Kota Pontianak terletak di dekat saluran drainase dan badan Sungai Kapuas. Saluran Drainase RPH Sapi merupakan saluran yang dibangun sebagai pembatas antara lahan RPH Sapi dan pemukiman warga yang juga dimanfaatkan warga untuk kegiatan Mandi Cuci Kakus (MCK). RPH Sapi sudah memiliki Instalasi Pengolahan Air Limbah (IPAL) namun masih menimbulkan pencemaran terhadap lingkungan sekitar. Untuk itu perlu dianalisa seberapa besar pencemaran limbah cair dan beban pencemaran terhadap saluran drainase dan badan Sungai Kapuas. Tahapan dalam penelitian ini yakni dengan menghitung kecepatan aliran, perhitungan debit aliran, pengambilan sampel air dan perhitungan beban pencemaran. Pengambilan sampel air dilakukan dengan metode pengambilan sesaat (grab sample) pada kondisi pasang dan surut di 4 titik pada saluran drainase, 1 effluen, dan 2 bak pengolahan biologi dengan parameter pencemar yaitu $\mathrm{BOD}, \mathrm{COD}, \mathrm{TSS}, \mathrm{NH}_{3}-\mathrm{N}$, minyak dan lemak, dan $\mathrm{pH}$ yang diuji di laboratorium. Hasil uji laboratorium akan dianalisa dan dibandingkan dengan baku mutu air pada Permen LH NO.05 tahun 2014 untuk air limbah dan PP Nomor 82 tahun 2001 untuk air drainase. Kualitas air limbah dilihat dari bak pengolahan akhir IPAL RPH berada di bawah ambang baku mutu. Konsentrasi kualitas air drainase sebelum RPH pada saat pasang parameter BOD 17,12 mg//; COD $96 \mathrm{mg} / \mathrm{l}$; TSS $30 \mathrm{mg} / \mathrm{l} ;$ Amonia 1,43 mg/l; Minyak dan Lemak 0,025 mg/l; Ph 6,62. Saat surut konsentrasi pada parameter BOD 14,98 mg/l; COD $104 \mathrm{mg} / \mathrm{l} ;$ TSS $56 \mathrm{mg} / \mathrm{l}$; Amonia 8,61 mg/l; Minyak dan Lemak $0,025 \mathrm{mg} / \mathrm{l}$ dan $\mathrm{pH} 6,62$. Konsentrasi kualitas air drainase setelah RPH saat pasang pada parameter BOD Pada saat surut BOD 14,98 mg/l; COD 76 mg/l; TSS 40 mg/l; Amonia 2,94 mg/l; Minyak dan Lemak 0,025 mg/l dan pH 6,8. Pada saat surut BOD 21,4 mg/l; COD $168 \mathrm{mg} / \mathrm{l} ;$ TSS 44 $\mathrm{mg} / \mathrm{l}$; Amonia 5,59 mg/l; Minyak dan Lemak 0,025 mg/l dan pH 6,8. Hasil penelitian kualitas air disaluran drainase RPH Sapi Beban Pencemaran pada kondisi pasang yakni BOD $131 \mathrm{~kg} / \mathrm{hari}$, COD $588 \mathrm{~kg} / \mathrm{hari}$, TSS $508 \mathrm{~kg} / \mathrm{hari}$, amonia $8 \mathrm{~kg} / \mathrm{hari}$, dan minyak dan lemak 3,67 kg/hari. Pada kondisi surut beban pencemaran adalah sebesar BOD $139 \mathrm{~kg} / \mathrm{hari}$, COD $748 \mathrm{~kg} / \mathrm{hari}$, TSS 305 $\mathrm{kg} / \mathrm{hari}$, amonia $10 \mathrm{~kg} / \mathrm{hari}$, dan minyak dan lemak $1,18 \mathrm{~kg} / \mathrm{hari}$.
\end{abstract}

Kata Kunci : RPH Sapi Kota Pontianak, saluran drainase, beban pencemaran

\begin{abstract}
Concomitant increase demand for meat in the public so they really need a good Cow Slaughter House (RPH) which demand of clean, healthy and halal consumed. Cows slaughterhouse is located near the Kapuas river drainage. The drainage canal of cow slaughter is a canal that was built as a divider between cows slaughterhouse area and residential areas which functioned by civilian peoples activity. Cows slaughterhouse had own their waste water treatment plant, but still make some pollution to the surrounding environment. Because of that need to analyze how much pollution and waste water poluution load of the drainage canals and agencies kapuuas river. Steps in this research using the calculation of the flow velocity, collecting primary data, measurement and, flow rate calculation, water sampling and calculation of pollution load. Taking of water sample use grab sample method when the condition are current up and down at 4 point at drainage canal, one effluent and two biological treatments with the pollutant parameters are $B O D, C O D, T S S, \mathrm{NH}_{3}-\mathrm{N}$, Oil-grease, and $\mathrm{pH}$ tested in the laboratory. Concentration of drainage water quality parameters before RPH when current up are BOD 17,12 mg/l; COD $96 \mathrm{mg} / \mathrm{l}$; TSS 30
\end{abstract}


mg/l; Amoniac 1,43 mg/l; oil and grease 0,025 mg/l; Ph 6,62. Concentration of drainage water quality parameters before RPH appears when current down are BOD 14,98 mg/l; COD $104 \mathrm{mg} / \mathrm{l}$; TSS $56 \mathrm{mg} / \mathrm{l}$; Amonia 8,61 mg/l; Oil and grease 0,025 mg/l and $\mathrm{pH} \mathrm{6,62.} \mathrm{Concentration} \mathrm{of}$ drainage water quality parameters after RPH appears when current up are BOD 14,98 mg/l; COD $76 \mathrm{mg} / \mathrm{l}$; TSS $40 \mathrm{mg} / \mathrm{l}$; Amoniac 2,94 mg/l; Oil and grease 0,025 mg/l and $\mathrm{pH}$ 6,8. And when current down parameters are BOD 21,4 mg/l; COD $168 \mathrm{mg} / \mathrm{l}$; TSS $44 \mathrm{mg} / \mathrm{l}$; Amoniac 5,59 mg/l; Oil and Grease $0,025 \mathrm{mg} / \mathrm{l}$ and $\mathrm{pH} 6,8$. Results of water quality cows slaughter drainage canals show pollution load when current up are BOD $131 \mathrm{~kg} /$ day, COD $588 \mathrm{~kg} /$ day, TSS $508 \mathrm{~kg} /$ day, amonia 8 $\mathrm{kg} /$ day, dan minyak dan lemak 3,67 kg/day. pollution load when current down are BOD 139 kg/day, COD $748 \mathrm{~kg} /$ day, TSS $305 \mathrm{~kg} /$ day, amonia $10 \mathrm{~kg} /$ day, and oil and grease 1,18 kg/day.

Keywords: lowercase, consists of 3-10 words, separated by ommas

\section{PENDAHULUAN}

Rumah Potong Hewan adalah (RPH) adalah suatu bangunan atau komplek bangunan dengan desain dan konstruksi khusus yang memenuhi persyaratan teknis dan higienis tertentu serta digunakan sebagai tempat pemotongan hewan (Peraturan Pemerintah Lingkungan Hidup, 2006). RPH Sapi Kota Pontianak merupakan satu-satunya RPH resmi yang terletak berdampingan dengan salah satu parit di Kecamatan Nipah Kuning Pontianak yang juga berbatasan langsung dengan Sungai Kapuas (Sriwiyanti, 2013).

Darah umumnya mengandung uric acid yang merupakan racun / toxic yang berbahaya bagi kesehatan kita. Uric acid yang ada di dalam tubuh kita akan dibawan darah yang kemudian akan dibuang ke luar tubuh dengan air urin / air kencing melalui ginjal. Minum darah atau memakan makanan yang tidak bersih dari darah dapat membuat kita keracunan atau memperberat kerja dari organ ginjal kita yang berharga. Limbah dari pemotongan hewan sapi umumnya memiliki kandungan $\mathrm{pH}, \mathrm{BOD}, \mathrm{COD}, \mathrm{TSS}$, Minyak dan Lemak, dan $\mathrm{NH}_{3}-\mathrm{N}$. Parameter tersebut akan bersifat toxic dan akan mengganggu keberadaan biota lain apabila bersifat berlebihan (Padmono, 2005).

Air merupakan sumber daya alam yang diperlukan untuk hajat hidup orang banyak, bahkan oleh semua makhluk hidup. Oleh karena itu, sumber daya air harus dilindungi agar tetap dapat dimanfaatkan dengan baik oleh manusia serta makhluk hidup yang lain (Effendi, 2003). Klasifikasi mutu air ditetapkan menjadi 4 kelas menurut PP No. 82 tahun 2001, yaitu diperuntukan untuk air baku air minum pada kelas I, untuk rekreasi pada kelas II, untuk perikanan pada kelas III, dan pertanian pada kelas IV.

Baku mutu air limbah bagi kegiatan RPH adalah ukuran batas atau kadar maksimum unsur pencemar dan/atau jumlah pencemar yang ditenggang keberadaannya dalam air limbah kegiatan RPH yang akan dibuang atau dilepas ke media lingkungan (Permen LH No 02/2006). Limbah ternak adalah sisa buangan dari suatu kegiatan usaha peternakan seperti usaha pemeliharaan ternak, rumah potong hewan, pengolahan produk ternak, dan sebagainya. Limbah tersebut meliputi limbah padat dan limbah cair seperti feses, urine, sisa makanan, embrio, kulit telur, lemak, darah, bulu, kuku, tulang, tanduk, isi rumen, dan lain-lain (Sihombing, 2000).

Tinja dan urine dari hewan yang tertular dapat sebagai sarana penularan penyakit, misalnya saja penyakit anthrax melalui kulit manusia yang terluka atau tergores. Spora anthrax dapat tersebar melalui darah atau daging yang belum dimasak yang mengandung spora. Kasus anthrax sporadik pernah terjadi di Bogor tahun 2001 dan juga pernah menyerang Sumba Timur tahun 1980 dan burung unta di Purwakarta tahun 2000 (Soeharsono, 2002).

Rumah Potong Hewan (RPH) sapi yang ada di Jalan Pelabuhan Rakyat Kecamatan Pontianak Barat merupakan rumah potong hewan resmi milik pemerintah yang difungsikan dengan adanya proses pengolahan limbah. Menurut Sriwiyanti (2013) RPH 
Sapi di Nipah Kuning sudah delangkapi dengan Instalasi Pengolahan Air Limbah (IPAL) namun masih menimbulkan pencemaran di lingkungan sekitar. Limbah cair berupa darah hewan yang dipotong serta air hasil pencucian daging langsung dialirkan ke bakbak pengolahan yang berdampingan dengan parit di Nipah Kuning dan juga Sungai Kapuas. Dari uraian latar belakang tersebut maka adanya RPH sapi di Pontianak Barat perlu dilakukan analisa air saluran drainase, air sungai, dan air limbahnya untuk mengetahui apakah terdapat pencemaran yang bersumber dari limbah RPH sapi.

\section{METODOLOGI PENELITIAN}

\section{A. LOKASI DAN WAKTU PENELITIAN}

Penelitian ini dilakukan di Rumah Potong Hewan Sapi yang bertempat di Jalan Pelabuhan Rakyat Kecamatan Pontianak Barat. Penelitian dilakukan selama 6 (enam) bulan, mulai dari bulan Mei sampai dengan bulan Oktober 2015. Sedangkan analisis BOD, COD, TSS, $\mathrm{NH}_{3}-\mathrm{N}$, minyak dan lemak dan $\mathrm{pH}$ dilakukan di Laboratorium PT.SUCOFINDO Pontianak. Analisis pH dilakukan langsung pada saat pengambilan sampel. Pengambilan sampel dilakukan tanggal 15 juni 2015 pada kondisi pasang (pukul 17.00 WIB) dan tanggal 16 juni 2015 kondisi surut (pukul 06.30 WIB). Pengambilan sampel dilakukan pada 4 titik sepanjang saluran yakni sebelum melewati RPH Sapi (titik 1), berdampingan dengan RPH (titik 2), setelah RPH (titik 3), dan muara saluran (titik 4). Penelitian ini merupakan penelitian deskriptif dengan pendekatan kuantitatif untuk menggambarkan kondisi kualitas air di wilayah studi.

\section{B. ALAT DAN BAHAN}

$>$ Alat

Penelitian ini diawali dengan tahap persiapan yang meliputi penyediaan alat penelitian di lapangan diantaranya GPS (Global Positioning System), stopwatch, botol sampel, bola kasti, bak ukur, current meter, pH meter, termometer, pita ukur dan termos pendingin.

\section{Bahan}

Adapun bahan-bahan yang digunakan dalam penelitian ini adalah sampel air, sampel air limbah, dan es batu.

\section{PROSEDUR PENELITIAN}

Pada penelitian ini dilakukan pengukuran dimensi saluran (lebar dan kedalaman saluran), kecepatan aliran, perhitungan debit aliran dan perhitungan baban pencemaran. Perhitungan kecepatan air dilakukan menggunakan pelampung (bola kasti). Bola kasti dilairkan diatas saluran air dengan jarak $10 \mathrm{~m}$ dan dihitung waktu tempuh dengan stopwatch. Pengukuran kecepatan aliran air dan pengambilan sampel air dilakukan dalam waktu bersamaan.

Pengambilan sampel air dilakukan dengan teknik pengambilan sampel sesaat (grab sampel). Pengambilan sampel air diambil secara vertikal dan komposit. Botol sampel air kemudian diberi label dan dimasukan ke dalam termos pendingin yang telah diberi batu es dan kemudian diuji di Laboratorium. Hasil yang didapat kemudian dianalisis dengan membandingkan dengan standar baku mutu air pada PP RI No.82 tahun 2001 tentang Pengelolaan Kualitas Air dan Pengendalian Pencemaran Air. 


\section{HASIL DAN PEMBAHASAN}

Kecepatan aliran merupakan perhitungan awal yang dilakukan setelah mendapatkan nila kedalaman dan lebar saluran, dan waktu tempuh bola. Hasil perhitungan kecepatan aliran dapat dilihat pada Tabel 1. beriukut:

Tabel 1. Kecepetan dengan Pelampung (Bola Kasti)

\begin{tabular}{ccccccc}
\hline \multirow{2}{*}{ No } & \multirow{2}{*}{ Lokasi } & \multicolumn{2}{c}{ Waktu (detik) } & Jarak & \multicolumn{2}{c}{ Kecepatan (m/detik) } \\
\cline { 3 - 7 } & & Pasang & Surut & $(\mathrm{m})$ & Pasang & Surut \\
\hline 1 & Titik 1 & 2564,67 & 1275,27 & 10 & 0,00390 & 0,008 \\
2 & Titik 2 & 2082,67 & 996,67 & 10 & 0,00480 & 0,010 \\
3 & Titik 3 & 2086,33 & 691,67 & 10 & 0,00479 & 0,014 \\
4 & Titik 4 & 1549,67 & 513,33 & 10 & 0,00645 & 0,019 \\
\hline
\end{tabular}

Dari data hasil kecepatan aliran dapat diperoleh nilai debit aliran. Debit aliran pada lapangan dikalikan dengan debit bola pada saat kalibrasi seperti pada Tabel 2. Berikut:

Tabel 2. Debit Aliran

\begin{tabular}{cccc}
\hline \multirow{2}{*}{ Lokasi } & Hit Debit Bola & \multicolumn{2}{c}{$\begin{array}{c}\text { Debit Setelah Kalibrasi } \\
\text { (m3/dtk) }\end{array}$} \\
& & \multicolumn{3}{c}{ Pasang } & Surut \\
\cline { 2 - 4 } & $\mathrm{m} 3 /$ detik & 0,005 & 0,002 \\
\hline Titik 1 & 0,00023 & 0,017 & 0,01 \\
Titik 2 & 0,0006 & 0,008 & 0,007 \\
Titik 3 & 0,00102 & 0 & 0 \\
Titik 4 & 0,00151 & & \\
\hline
\end{tabular}

Hasil pengujian sampel air pada saluran drainase Rumah Potong Hewan Kota Pontianak dengan 6 parameter uji dapat dilihat pada Table 3 dan Tabel 4. berikut:

Tabel 3. Hasil Uji Kondisi Pasang

\begin{tabular}{cccccccc}
\hline & & \multicolumn{6}{c}{ Parameter } \\
\cline { 3 - 8 } No & Lokasi & \multicolumn{7}{c}{ Minyak dan Lemak } & $\mathrm{pH}$ \\
\cline { 3 - 8 } & & BOD & COD & TSS & NH3-N & 0,025 & 6,62 \\
\hline 1 & Titik 1 & 17,12 & 96 & 30 & 1,43 & 0,025 & 7,82 \\
2 & Titik 2 & 183,6 & 734,4 & 696 & 5,6 & 0,025 & 6,8 \\
3 & Titik 3 & 14,98 & 76 & 40 & 2,94 & 0,025 & 6,78 \\
4 & Titik 4 & 17,12 & 128 & 116 & 3,23 & & \\
\hline
\end{tabular}


Tabel 4. Hasil Uji Kondisi Surut

\begin{tabular}{cccccccc}
\hline & & \multicolumn{7}{c}{ Parameter } \\
\cline { 3 - 8 } No & Lokasi & \multicolumn{7}{c}{ Minyak dan Lemak } & pH \\
\cline { 3 - 8 } & & BOD & COD & TSS & NH3-N & 0,025 & 6,62 \\
\hline 1 & Titik 1 & 14,98 & 104 & 56 & 8,61 & 0,025 & 7,82 \\
2 & Titik 2 & 391,7 & 1958,4 & 844 & 9,8 & 0,025 & 6,8 \\
3 & Titik 3 & 21,4 & 168 & 44 & 5,09 & 0,025 & 6,78 \\
4 & Titik 4 & 21,4 & 144 & 48 & 5,59 & &
\end{tabular}

Dari Tabel 3. Dan Tabel 4. Dapat dihitung konsentrasi dari setiap parameter dan digambarkan dalam grafik seperti Gambar 1-5 berikut:



Gambar 1. Grafik Sebaran Parameter BOD

Gambar 1. menunjukan sebaran konsentrasi parameter BOD. Dari grafik tersebut dapat diketahui bahwa titik 2 merupakan titik yang memiliki konsentrasi terbesar pada kondisi pasang maupun surut.

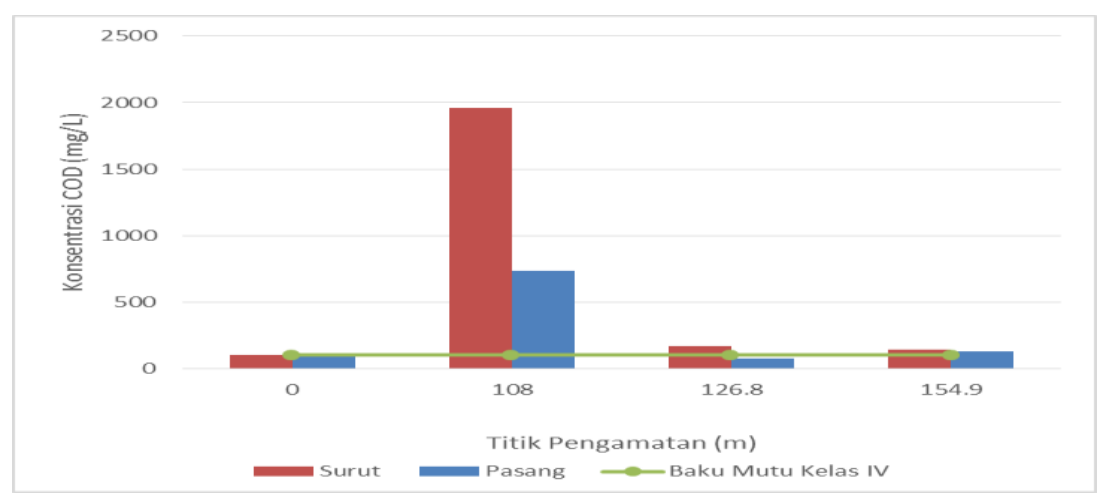

Gambar 2. Grafik Sebaran Parameter COD

Gambar 2. menunjukan sebaran konsentrasi parameter COD. Dari grafik tersebut dapat diketahui bahwa titik 2 merupakan titik yang memiliki konsentrasi terbesar pada kondisi pasang maupun surut. 


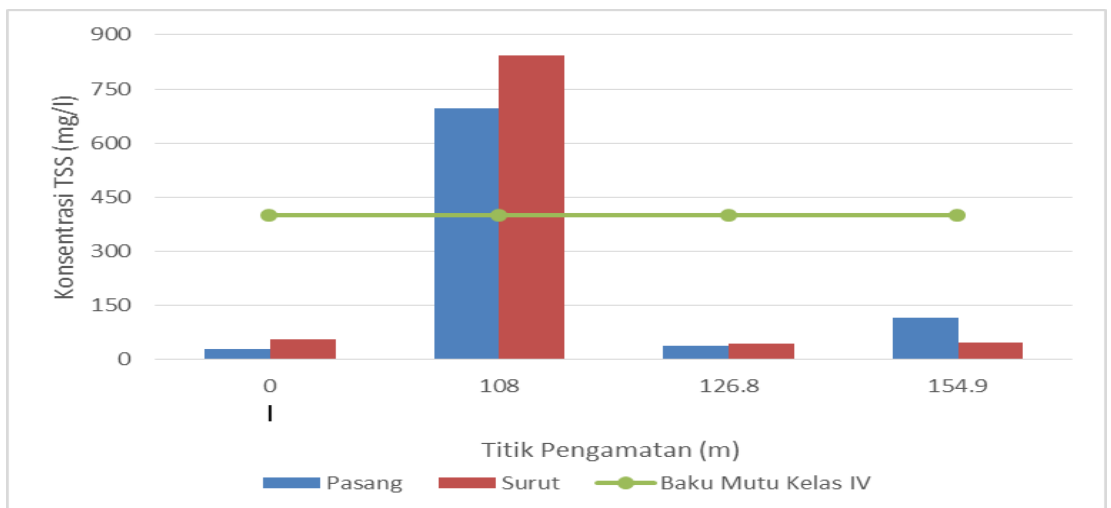

Gambar 3. Grafik Sebaran Parameter TSS

Gambar 3. menunjukan sebaran konsentrasi parameter TSS. Dari grafik tersebut dapat diketahui bahwa titik 2 merupakan titik yang memiliki konsentrasi terbesar pada kondisi pasang maupun surut.

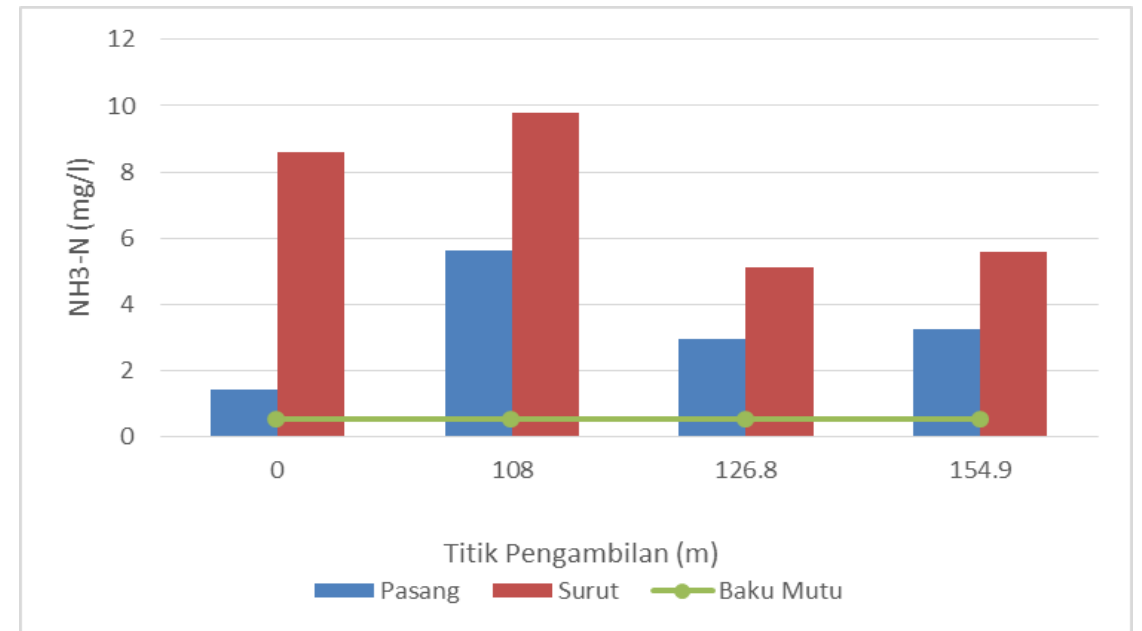

Gambar 4. Grafik Sebaran Parameter Amonia

Gambar 4. menunjukan sebaran konsentrasi parameter TSS. Dari grafik tersebut dapat diketahui bahwa titik 2 merupakan titik yang memiliki konsentrasi terbesar pada kondisi pasang maupun surut.

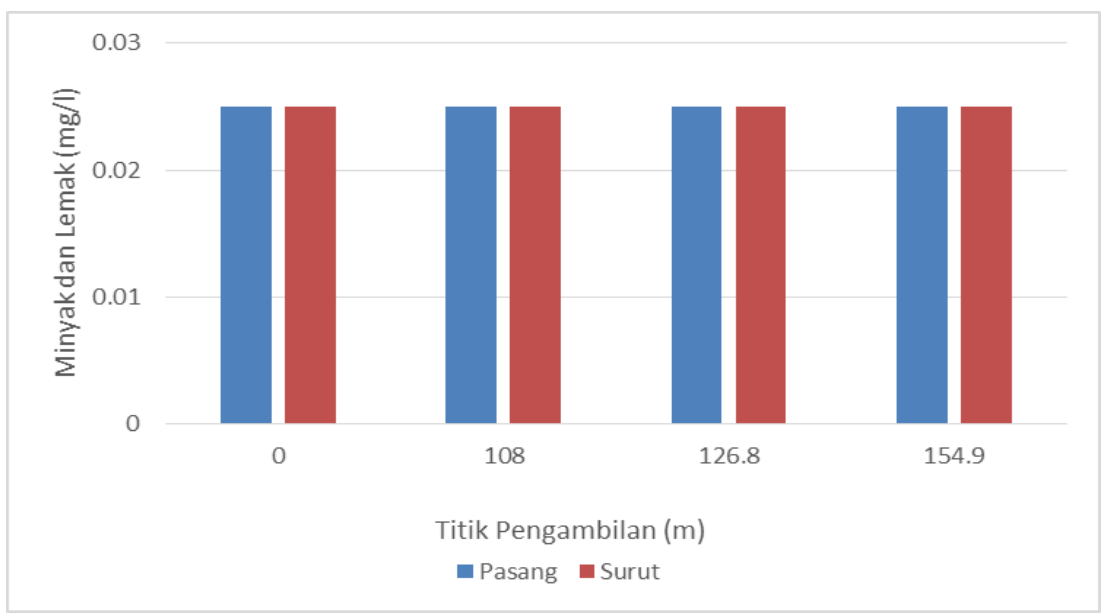

Gambar 5. Grafik Sebaran Parameter Minyak dan Lemak 
Gambar 5. menunjukan sebaran konsentrasi parameter TSS. Dari grafik tersebut dapat diketahui bahwa titik 2 merupakan titik yang memiliki konsentrasi terbesar pada kondisi pasang maupun surut.

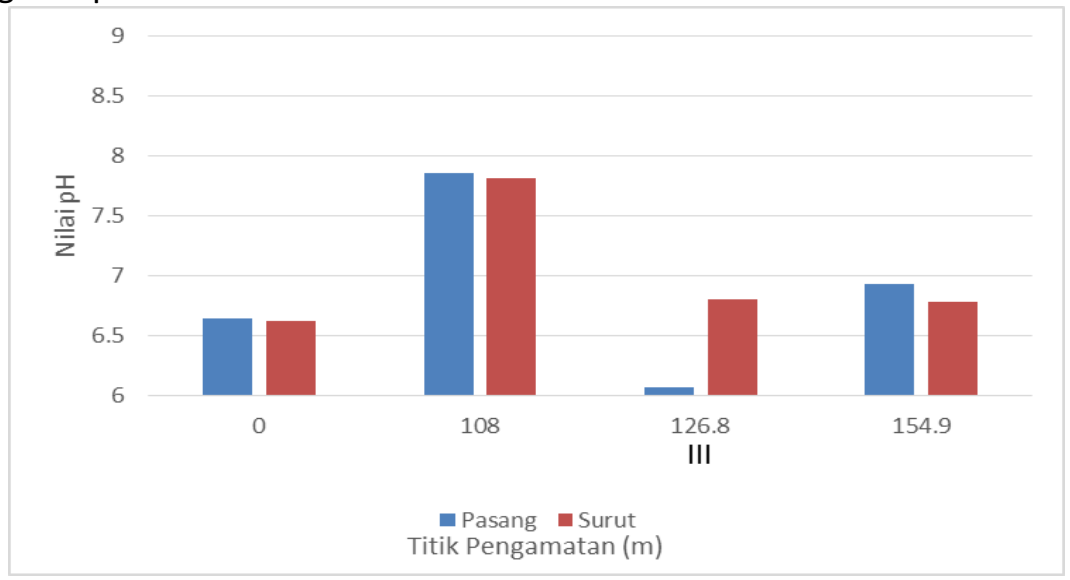

Gambar 6. Grafik Sebaran Parameter pH

Gambar 6. menunjukan sebaran konsentrasi parameter TSS. Dari grafik tersebut dapat diketahui bahwa titik 2 merupakan titik yang memiliki konsentrasi terbesar pada kondisi pasang maupun surut.

Dapat dilihat dari hasil uji bahwa titik 2 mempunyai konsentrasi paling tinggi disetiap parameter dan kondisi. Titik 2 merupakan titik yang berada tepat berdampingan dengan RPH. Limbah yang belum melalui proses pengolahan di Instalasi Pengolahan Air Limbah secara sempurna masuk ke badan saluran. Selain itu sumber pencemar lain seperti tinja dan limbah RPH yang jatuh ke drainase yang berdekatan dengan titik 2 mengakibatkan konsentrasi ditik 2 menjadi besar. Aliran limbah dari RPH dapat dilihat dari Gambar 7. Berikut:

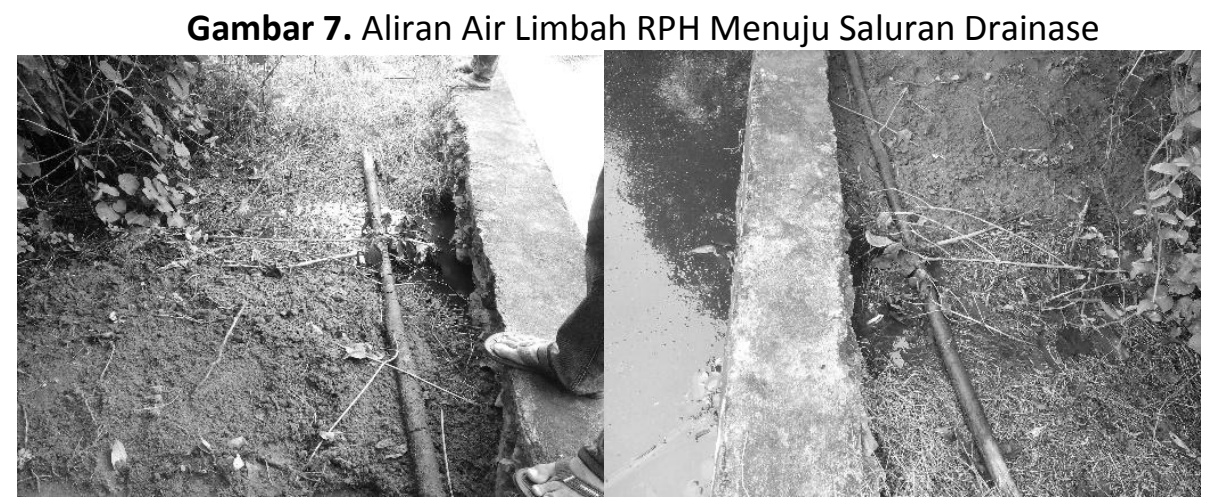

Kondisi pasang merupakan kondisi dimana arah aliran berasal dari bagian hilir (titik 4) menuju bagian hulu saluran (titik 1). Dari hasil pengujian pada kondisi pasang parameter BOD terendah terdapat pada titik 3 yaitu 14,8 mg/l dan $76 \mathrm{mg} / \mathrm{l}$ untuk parameter COD. Menurut (Agusnar. H, 2008) Nilai BOD selalu lebih kecil dari pada nilai COD diukur pada senyawa organik yang dapat diuraikan maupun senyawa organik yang tidak dapat berurai. Analisis BOD dan COD dari suatu limbah akan menghasilkan nilainilai yang berbeda karena kedua uji mengukur parameter yang berbeda. Nilai-nilai COD selalu lebih tinggi dari pada nilai BOD. Untuk parameter NH3-N terkecil pada kondisi pasang berada pada titik 1 yakni $1,43 \mathrm{mg} / \mathrm{l}$ dan TSS yakni $30 \mathrm{mg} / \mathrm{l}$. Faktor yang 
mempengaruhi perubahan konsentrasi amonia di sepanjang aliran sungai antara lain debit aliran, pengenceran dan kondisi aliran itu sendiri seperti keberadaan sampahsampah dan rumput liar yang mengendapkan TSS. Kemampuan selfpurification dari drainase RPH juga mengakibatkan turunnya parameter amonia dan TSS di titik 1. Parameter minyak dan lemak memiliki nilai dibawah $0,025 \mathrm{mg} / \mathrm{l}$ di semua titik dan masih bernilai dibawah ambang baku mutu air permukaan. Parameter $\mathrm{pH}$ terendah terdapat pada titik 1 yakni 6,62.

Kondisi surut merupakan kondisi aliran air mengarah dari bagian hulu (titik 1) menuju titik bagian hilir (titik 4). Pada kondisi ini nilai terendah parameter BOD berada pada titik 1 yakni 14,98 mg/l dan COD yakni $104 \mathrm{mg} / \mathrm{l}$ dan $\mathrm{pH}$ sebesar 6,62. Untuk konsentrasi terendah berada dititik 3 yakni parameter $\mathrm{NH}_{3}-\mathrm{N}$ sebesar $5,09 \mathrm{mg} / \mathrm{l}$, minyak dan lemak sebesar dibawah $0,025 \mathrm{mg} / \mathrm{L}$. Selain karena nilai yang terlalu kecil pengenceran juga mempengaruhi kecilnya konsentrasi pada parameter tersebut.

Dari hasil analisa parameter di setiap titik dapat di peroleh angka rata-rata dengan mengacu pada Permen LH no.110 tahun 2003 tentang perhitungan baku mutu dan beban pencemaran rata-rata. Hasil tersebut dapat digambarkan dalam sebuah grafik seperti pada Gambar 8. Berikut:

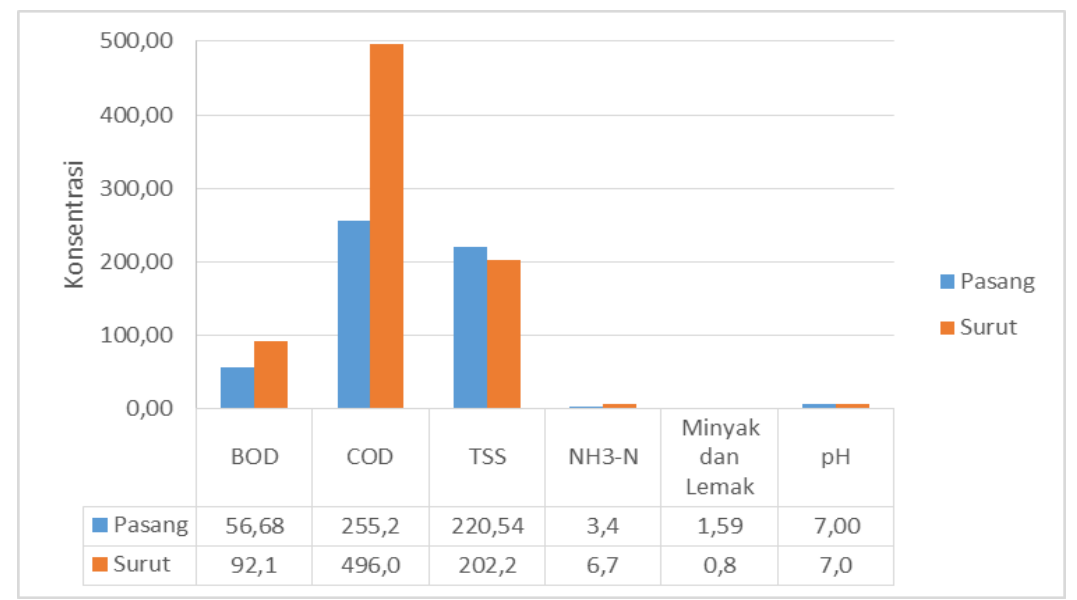

Gambar 8. Grafik hasil konsentrasi rata-rata parameter uji

Setelah mendapatkan konsentrasi disetiap parameter dapat dihitung beban pencemaran. Menurut Peraturan Pemerintah No.82 Tahun 2001 beban pencemaran adalah jumlah suatu pencemar yang terkandung di dalam air atau air limbah. Beban pencemaran sungai adalah jumlah suatu unsur pencemar yang terkandung dalam air sungai. Beban pencemar sungai dapat disebabkan oleh adanya aktivitas industri, pemukiman dan pertanian.

Besarnya beban pencemaran dapat diperoleh dengan persamaan (Mitsch danGoesselink, 1993 dalamMargonof, 2007):

$$
B P S=(C s) j \times Q s \times f \text {. }
$$

Keterangan:

BPS= Beban pencemaran sungai $(\mathrm{kg} / \mathrm{hari})$

$(C s) j=$ Kadar terukur sebenarnya unsur pencemar $j$

( $\mathrm{j}=$ parameter)(mg/liter)

Qs= Debit air sungai (m3/hari)

$\mathrm{f}=$ faktor konversi $=\frac{1 \mathrm{~kg}}{1.000 .000 \mathrm{mg}} \times \frac{1000 \text { liter }}{1 \mathrm{~mm}^{\mathrm{g}}} \ldots$ 
Hasil perhitungan beban pencemaran saluran drainase RPH Sapi dapat dilihat pada Tabel 5. berikut:

Tabel 5. Beban Pencemaran Pada Saat Pasang Dan Surut

\begin{tabular}{|c|c|c|c|c|c|c|}
\hline \multirow{2}{*}{ No } & \multirow{2}{*}{ Lokasi } & \multicolumn{5}{|c|}{ Beban Pencemaran (Kg/Hari) } \\
\cline { 3 - 7 } & & BOD & COD & TSS & NH3-N & Minyak dan Lemak \\
\hline \multirow{2}{*}{1} & Pasang & 131 & 588 & 508 & 8 & 3,67 \\
\hline 2 & Surut & 139 & 748 & 305 & 10 & 1,18 \\
\hline \multicolumn{2}{|c}{ Total } & 270 & 1336 & 813 & 18 & 4,85 \\
\hline
\end{tabular}

Dari nilai Tabel 5. Dapat diperoleh gambar grafik beban pencemaran yakni Gambar 9 Berikut:

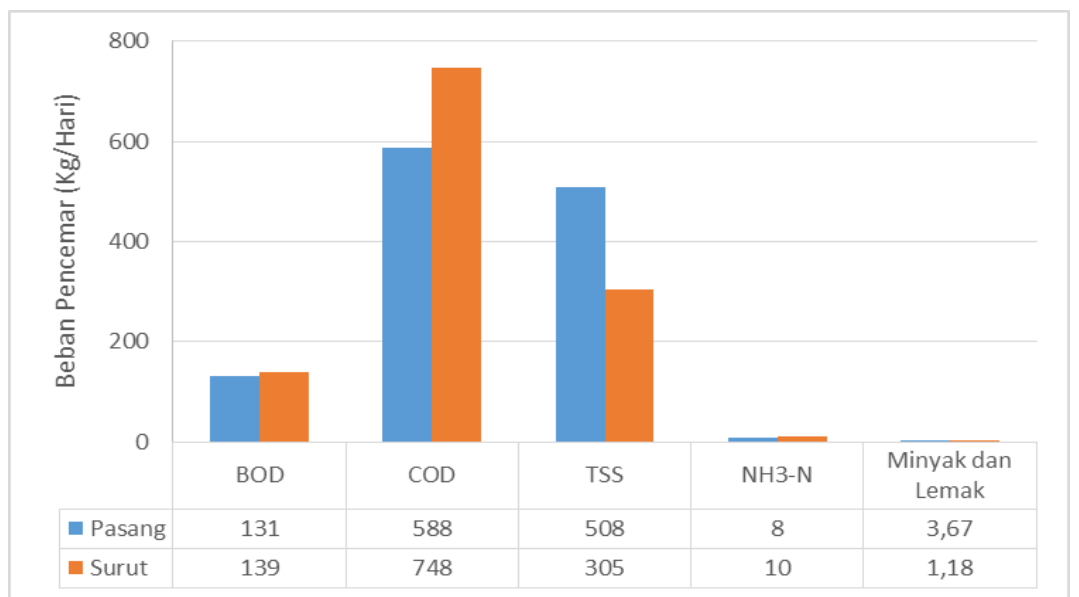

Gambar 9. Grafik Beban Pencemaran Saluran Drainase RPH Sapi Pada Kondisi Pasang dan Surut

Rata-rata beban pencemaran yang disumbangkan oleh saluran drainase RPH Sapi di Nipah Kuning yang memiliki konsentrasi tertinggi adalah parameter COD yaitu $588 \mathrm{~kg} /$ hari pada saat pasang dan $748 \mathrm{~kg} /$ hari pada saat surut. Beban pencemaran lebih kecil pada saat pasang karena adanya pengenceran pada saat kondisi pasang. Voleme air drainase yang bertambah pada saat pasang mengakibatkan proses pengenceran dan pembilasan berjalan lebih baik.

\section{KESIMPULAN}

Adapun kesimpulan dari penelitian ini adalah:

1. Kualitas air limbah dilihat dari bak pengolahan akhir IPAL RPH berada di bawah ambang baku mutu sesuai dengan Baku Mutu Air Limbah Bagi Kegiatan Rumah Pemotongan Hewan menurut Peraturan Menteri Lingkungan Hidup Nomor 05 Tahun 2014.

2. Konsentrasi kualitas air drainase sebelum RPH pada saat pasang parameter BOD 17,12 mg/l; COD 96 mg/l; TSS 30 mg/l; Amonia 1,43 mg/l; Minyak dan Lemak 0,025 $\mathrm{mg} / \mathrm{l} ; \mathrm{Ph} 6,62$. Saat surut konsentrasi pada parameter BOD 14,98 mg/l; COD 104 $\mathrm{mg} / \mathrm{l} ; \mathrm{TSS} 56 \mathrm{mg} / \mathrm{l}$; Amonia 8,61 mg/l; Minyak dan Lemak 0,025 mg/l dan pH 6,62. Konsentrasi kualitas air drainase setelah RPH saat pasang pada parameter BOD Pada saat surut BOD 14,98 mg/l; COD 76 mg/l; TSS 40 mg/l; Amonia 2,94 mg/l; 
Minyak dan Lemak 0,025 mg/l dan pH 6,8. Pada saat surut BOD 21,4 mg/l; COD 168 $\mathrm{mg} / \mathrm{l} ;$ TSS $44 \mathrm{mg} / \mathrm{l}$; Amonia 5,59 mg/l; Minyak dan Lemak 0,025 mg/l dan pH 6,8.

3. Beban Pencemaran pada kondisi pasang yakni BOD $131 \mathrm{~kg} / \mathrm{hari}$, COD $588 \mathrm{~kg} / \mathrm{hari}$, TSS 508 kg/hari, amonia 8 kg/hari, dan minyak dan lemak 3,67 kg/hari. Pada kondisi surut beban pencemaran adalah sebesar BOD $139 \mathrm{~kg} / \mathrm{hari}$, COD $748 \mathrm{~kg} / \mathrm{hari}$, TSS $305 \mathrm{~kg} / \mathrm{hari}$, amonia $10 \mathrm{~kg} / \mathrm{hari}$, dan minyak dan lemak 1,18 kg/hari.

\section{UCAPAN TERIMA KASIH}

Terima kasih saya ucapkan kepada Allah SWT karena dengan rahmatnya penelitian ini bisa selesai. Terimakasih juga kepada orang tua, abang, adik, pacar serta teman-teman yang telah membantu dan mendukung saya dalam perkuliahan sampai di titik akhir yakni skripsi.

Terima kasih saya ucapkan untuk pembimbig saya Bapak DR. Ir. Johnny MTS, M.Sc dan Ibu Ir. Hj. RR Endang Mulyani yang telah setia membimbing saya. Semoga penelitian ini dapat bermanfaat bagi penulis maupun pembaca.

\section{DAFTAR PUSTAKA}

Agusnar, H. 2008. Analisa Pencemaran dan Pengendalian Lingkungan. Medan. USU Press.

Effendi, H. 2003. Telaah Kualitas Air Bagi Pengelolaan Sumber Daya Alam dan Lingkungan Perairan. Penerbit Kanisius, Yogyakarta

Padmono, Djoko. 2005. Alternatif Pengolahan Rumah Potong Hewan - Cakung. Jawa Barat

Peraturan Menteri Lingkungan Hidup. 2014. Keputusan Menteri Negara Lingkungan Hidup Nomor 5 Pedoman Penetapan Daya Tampung Beban Pencemaran Air Pada Sumber Air. Kementrian Lingkungan Hidup. Jakarta.

Peraturan Pemerintah. 2001. Peraturan Pemerintah Republik Indonesia Nomor 82 Pengelolaan Kualitas Air dan Pengendalian Pencemaran Perairan. Sekretaris Negara Republik Indonesia. Jakarta.

Sihombing, T. 2000. Pinang Budi Daya dan Prospek Bisnis. Penebar Swadaya. Jakarta.

Soeharsono. 2002. Penyakit Menular dari Hewan ke Manusia. Volume 1.Yogyakarta: Kanisius. $79-80$

Sriwiyanti, Endang. 2010. Evaluasi Rumah Potong Hewan Sapi Kota Pontianak. Universitas Gadjah Mada. Yogyakarta 